\title{
ATUALIDADE
}

\section{Sobre a Bienal de Número XIII}

\author{
Wilcon Pereira
}

"Esta é a Bienal da pressa"
um jornalista

"Coisa bonita tem que ser feita devagar"

indígenas do Xingu

\section{Notícias preliminares}

No começo de 1975 os jornais noticiaram: Francisco Matarazzo Sobrinho, Cicillo, afastava-se da direção da Bienal de São Paulo, que vinha presidindo desde 1951.

$\square$ como generoso e devotado mecenas, de prodigalidade esbanjadora, comentam alguns

de forma ditatorial e obscurantista, abusando do tráfico de influências e protegendo somente os afilhados, ao ver de outros

mas nenhuma pessoa deixaria de render expresso tributo à sua energia de autêntico capitão de indústria, força que lhe permitira inclusive, ano após ano, defender-se do golpe fatal

Agora se perpetrava, enfim, o crime primordial - a eliminação do Grande Pai. Quanto aos motivos: ninguém viu, ninguém sabe, ninguém se interessa por um relato coerente e documentado. Temse a impressão de que houve um acordo tácito e unânime - não se fala mais nisso e aguarda-se a diluição do nevoeiro de boatos. Toda história é remorso, no dizer do poeta.

Razões vagamente entrevistas, só para especularmos um pouco: obscuras questões financeiras e estatutárias, envolvendo a prefeitura da cidade, nova entidade mantenedora

$\square$ um irrecuperável desgaste da sua imagem pública, junto a artistas, críticos, membros da Fundação Bienal, outros empresários

falta das mais elementares condições para tentar um rejuvenescimento do projeto, constituindo equipes de trabalho, criando uma estrutura didático-pedagógica, mudando o sistema de premiação e até mesmo de convite para a grande mostra - a Fundação dirige-se sempre aos governos dos países e não diretamente aos artistas mais em evidência

O certo é que houve uma previsível e justificada inquietação nas paróquias, capelas e arraias das artes plásticas. $\mathrm{O}$ destino da Bienal parecia selado: obra e inventor desapareceriam juntos. Mas aí sobreveio outro fato decisivo, abrindo horizontes imprevistos. Em abril de 1975 todos os impasses foram superados: iniciava seus trabalho uma comissão presidida por Oscar Landmann. Seus integrantes dispunham apenas de seis meses para aprender o ofício e fazer cumprir o velho ritual - festiva inauguração em outubro, com discursos, autoridades, agitação dos convidados, fotó- 
grafos, quilômetros e quilômetros de obras de arte.

Tudo isso bem considerado, não há como deixar de reconhecer: foi mesmo uma significativa "vitória contra as adversidades", como lembrou um dos superintendentes (1). Pelo menos se julgarmos a partir de um critério puramente quantitativo:

$\square$ trinta mil metros quadrados a serem percorridos, 42 países participantes, cerca de quatro mil trabalhos, várias salas latino-americanas, centenas de artistas brasileiros, fotografias, jóias, retrospectiva de filmes nacionais, anteriores ao cinema-novo, sessões de teatro, quatrocentos mil cruzeiros em prêmios, gastos aproximados de dois milhões e meio (sem levar em conta, bem entendido, o capital aplicado pelas nações que enviaram seus representantes - viagens, catálogos, instalações, seguros, promoções sociais etc.)

Sem dúvida, "aquilo que normalmente se tem feito no prazo de ano e meio, foi desta vez realizado em cinco meses" (2)

\section{Julgando o júri}

Assim, na aparência externa, era mais uma Bienal como tantas outras.

está claro que sem as vantagens do ineditismo que marcou a primeira, aberta em 1951, pois em termos de problemas estéticos nos encontrávamos no pré-cubismo (para dizer o mínimo)

também infinitamente menos prestigiosa e rica como fonte de informação do que a segunda, a do IV Centenário,

(1) Declarações do Professor Paulo Natanael a "Artes Visuais", seção domininical da Folha de São Paulo, 12 de outubro de 1975 , p. 80 .

(2) idem, ibidem. expondo Mondrian, Pollock, Munch, Klee, Calder, o Guernica de Picasso.

$\square$ e visivelmente pouco aberta aos ventos da experimentação, que caracterizaram a Bienal IX, contando com a pop, os primeiros embriões da arte pobre, algumas radicais experiências de antiarte e de contracultura

Feitas estas ressalvas, no entanto, como distinguir a Bienal de hoje daquelas que a precederam? Não lhe faltaram sequer as costumeiras agitações de superfície, sons e fúrias inevitáveis em acontecimento social de tão grande importância. Nesse sentido, aliás, a principal contribuição viria do próprio júri internacional, presidido por Paulo Mendes de Almeida, um dos decanos de nossa crítica de arte. Sabe-se que as premiações, em tais oportunidades, são quase sempre eleições muito discutíveis, sujeitas a arbitrárias preferências individuais e até mesmo a influências políticas. Qualquer decisão é forçosamente polêmica e sujeita a cauções. Mas desta vez o seleto grupo de experts se encarregou de levar o fenômeno ao paroxismo, indo muito além da encomenda enquanto gerador de oposições, escândalos e descontentamentos:

alegando "falta de tempo e condições técnicas" não se detiveram no pavilhão dos Estados Unidos mais do que trinta minutos; a sofisticada, caríssima, babilônica retrospectiva da video-art exigia, no mínimo, oito horas de um espectador incansável e em boas condições físicas

resolveram não penetrar nas salas do grupo brasileiro Etsedron, uma montagem de ambientação nordestina, pois havia muita terra no chão

$\square$ além disso, não atribuíram qualquer galardão ao pintor hiper-realista espanhol Cristóbal Toral, que foi de longe o preferido do grande público, tão comovido pela sua habilidade no 
trompe-l'oeil quanto pela temática que figurava dramaticamente: a imigração e sua inevitável sequiela de misérias físicas e morais - malas, lanches, documentos, tristeza, saudade, desamparo.

Em consequiência, para a quase totalidade dos visitantes da XIII Bienal, tais esquecimentos e descasos julgavam em definitivo o próprio julgamento: incompetente, parcial, realizado de afogadilho e portanto desmerecedor de qualquer respeito. $\mathrm{E}$ as reclamações foram inevitavelmente de excepcional veemência, sobretudo as do inconformado Jack Boulton, comissário norte-americano, que chegou mesmo a pensar numa desmontagem de suas instalações como forma de protesto, só não o fazendo por respeito ao público.

\section{Antibienal}

Para finalizar a crônica dos rebuliços provocados, cabe ainda o registro de uma curiosa figura de compensação a que a XIII Bienal deu origem: a Bienal do Ano Dois Mil, instituída por Fred Forest, um artista francês de vanguarda.

Forest participa do movimento de arte sociológica, que pretende criar uma linguagem adequada à época atual, utilizando para isso os recursos da cultura de massa. Compareceu à Bienal de 73 com audiovisuais, manifestações de rua, folhas de papel oferecidas aos visitantes a fim de que se expressassem livremente, e várias outras formas de incentivo à participação direta do expectador. Este ano, talvez ao sentir-se marginalizado, resolveu agir por tabela, lançando sua própria Bienal: como se conceberá, na viragem do século, um festival de artes plásticas realizado em 1975? Lembrar-se-á por acaso de épcca já tão remota? E alguém se preocupará ainda com artes plásticas?
Para discutir essas questões (e formular outras) reuniu-se no Museu de Arte Contemporânea - no mesmo prédio da mostra oficial, bem atrás dela - um pequeno mas fervoroso grupo multidisciplinar de artistas visuais, pessoal de teatro, sociólogos e antropólogos, críticos, escritores, publicistas. Um dos aspectos mais instigantes da ação coletiva foi a pesquisa, no recinto do Parque Ibirapuera, de objetos que seriam depois examinados como fósseis e resíduos arqueológicos de nosso tempo.

No final das contas, mais um lance publicitário, logo assimilado e capitalizado pelos organizadores da Bienal. Que melhor demonstração de vitalidade se poderia imaginar? O filhote genial e up to date não dá razão (ao seu modo, evidentemente) à mãe pródiga e estimuladora?

\section{As adversidades no contra-ataque.}

Tudo assume um ar mais problemático no momento em que se passa às exigências qualitativas. Em última instância, qual o sentido informativo, cultural, estético-ideológico de uma tão dispendiosa manifestação? Neste nível, as avaliações foram quase unanimemente de caráter negativo, devastadoras as análises da imprensa especializada e do público mais participante: conservadora, anacrônica, palácio do já-visto, festival das vaidades, kitsch tamanho família, luxo/lixo, super-mercado das artes, e assim por diante.

Principalmente, reclamou-se de todas as formas possíveis contra a improvisação erigida em sistema, a pressa, o quebra-galho triunfante, a ausência de um projeto intelectual mais sério: tempo o catálogo não foi publicado a 
as peças de Mestre Dézinho, escultor popular do Piauí, ficaram nos caixotes e não puderam ser vistas pelo júri

os convites para a Sala de Arte Brasileira, de onde sairia o lote inicial do Museu do Artista Brasileiro (a ser brevemente inaugurado em Brasília), só foram expedidos nos últimos dias. Por isso mesmo faltou unidade conceptiva e maior critério de seleção, vieram trabalhos de porão ou marcados pela falta de acabamento, sem contar o não comparecimento de muitas figuras expressivas, que evidentemente se recusaram a pactuar com o lufa-lufa.

os encarregados da montagem física desta coletiva nacional também deram um inesperado auxílio à balbúrdia geral: os freqüentadores começavam a visita pelos mais jovens (Caciporé, Iracy) e terminavam-na, previsivelmente muito desorientados, diante de quadros de Anita Malfati e esculturas de Brecheret.

\section{Decisão metodológica}

Em reação ao que se diagnosticava como último suspiro da Bienal de São Paulo — a mediocridade do conjunto apresentado — às vezes se tentou ressaltar, num lance de generosidade, a excelência desta ou daquela representação isolada: todo o pavilhão da Espanha, as aquarelas de Cuevas, o senso de humor da figuração narrativa do português Batarda ou a sequiência fotográfica na qual o suíço Urs Lühti registrou as oscilações andróginas de seu próprio corpo.

Reconheçamos, logo de início, que no contexto surgiam com efeito notáveis exposições, capazes mesmo de tornar orgulhoso qualquer museu ou galeria. $\mathrm{E}$ não há fugir: seria pouco lúcido e esnobe não agarrar com firmeza a oportunidade, tão rara em nosso miserê cultural, de passar pela experiência de um contato direto, por exemplo, com as propostas de Jagoda Buic ou de José Luis Verdes.

Jagoda Buic recebeu o Grande Prêmio Internacional, pelas suas "formas tecidas", objetos de caráter tridimensional, que escapavam da tapeçaria plana convencional e aproximavam-se de esculturas. Matérias primas usadas: lã, crina de cavalo, sisal, cerdas de porco. O trabalho mais destacado era um gigantesco ambiente (uma tapeçaria/arquitetura, por assim dizer), articulando muitos volumes tecidos. O bloco, de irresistível apelo tátil, lembrava árvores, bichos, montes, nuvens. Saliências e reentrâncias davam origem a cavernas e percursos interiores, que podiam ser explorados pelos visitantes. Mas a artista iugoslava já vinha consagrada de antemão. Seu nome figura - junto com Lurçat, Magda Abakamovicz e poucos mais - entre os grandes responsáveis pela total renovação do gênero neste século. Além disso, em Bienal anterior, Jagoda se evidenciara de modo especial. E suas decisivas influências sobre a mais recente tapeçaria nacional também não eram segredo para ninguém. Assim, o júri mais cuidou de referendar uma glória viva do que propriamente de garimpar um talento.

$\square$ em compensação, o espanhol Verdes era relativamente desconhecido. Sua montagem, O Mito da Caverna, recebeu um dos vários premios internacionais. No interior de um recinto fechado, completamente vedado à luz natural (como a caverna do mito platônico, à qual se referia o trabalho) dispôs oito refletores que projetavam nas paredes as silhuetas de alguns manequins, feitos de madeira e representarido vultos humanos. Nessas mesmas paredes o autor fixou também inúmeros perfis de seres humanos, usando desta vez uma pintura a óleo, marrom sobre fundo bege. Em último lugar, o espectador era 
igualmente apanhado nessa trama, pois sua própria sombra começava a mover-se entre as demais, como um fantasma entre outros fantasmas. $\mathrm{O}$ conjunto pretendia simbolizar a vida contemporânea, uma cena de rua ou de qualquer aglomerado de pessoas agitadas, anônimas e solitárias.

Contudo, a atomização da gigantesca coletiva - seu desmembramento a fim de se realizar depois uma pinçagem de obras particulares - parece-nos justamente a posição mais ambígua, estéril e condenável, quando nos confrontamos com instituições culturais desta espécie. Por isso mesmo só nos interessa aqui, como opção de método, um enfoque distinto, o único que talvez seja capaz de fazer emergir novas perspectivas: um contínuo movimento de vaivém entre o global e os casos singulares. Pretendemos, assim, buscar a significação da mostra considerada na sua totalidade, mas sempre encadeando nossa visão desse todo complexo às leituras de determinadas proposições que o formam. Comenta-se desta maneira a XIII Bienal e, ao mesmo tempo, procura-se iluminar alguns de seus pontos mais estratégicos.

\section{O público em banho-maria}

Dentro desse plano, vamos lançar inicialmente uma hipótese bastante genérica: parece-nos de toda evidência que a marca profunda desta Bienal foi a monotonia, a inocultável sensação de perda de fôlego e arrefecimento.

"O ambiente acusava ausência de qualquer tensão", descreve um observador, "onde nenhuma descarga emocional, nenhuma ocorrência palpitante, dramática, por menor que seja, pudesse acontecer" (3)

(3) Eduardo Mercier - "Tadeus Brzozowski na XIII Bienal", in A Folha de São Paulo, 23 de nov. de 1975, p. 84.
De fato, essa era a atmosfera que envolvia a exposição internacional um desânimo, uma indiferença por tudo. Porém, a nosso ver, a fonte de tal mornidão deve ser localizada, ao menos em grande parte, no estado de espírito dos próprios frequientadores. Por mais paradoxal que soe, num primeiro momento: foi sobretudo a frieza geral das pessoas que levou ao malogro a Bienal de 1975. Este o dado novo, quase escandaloso. Impossível camuflar os deslizes da equipe organizadora, o precário nível médio das obras apresentadas, a atuação bufa do corpo de jurados ou mesmo o estado de decomposição em que se acha o velho prédio do Parque Ibirapuera. Todavia, esses fatores não eram propriamente inéditos. Ao contrário, em maior ou menor dose haviam comparecido em quase todas as Bienais precedentes.

já dissemos que algumas delas foram de alcance excepcional: a primeira, uma vez que se podia contar com as vantagens do inusitado e misterioso; a do IV Centenário, por representar um confronto ao vivo das principais tendências do período; a IX, de 1967 , com as vanguardas muito bem instaladas - arte de protesto, antiarte, arte pobre, environment, pop, op. Mas, por outro lado, todas as outras Bienais de São Paulo significaram também algo de muito decisivo. Cada uma delas, a seu modo, foi uma verdadeira situação-limite para o fruidor e produtor de arte no Brasil. Nem será preciso escrever muito a respeito. Basta recordar que sempre encorajavam - quando não introduziram, pura e simplesmente - as pesquisas e experimentações mais avançadas em seus respectivos momentos, do informalismo à arte mínima, do concretismo ao conceitualismo.

eis, contudo, o que nos interessa particularmente: os influxos eram vivenciados de imediato, ali mesmo, no interior da mostra, para logo depois, 
logo em seguida, repercutir e desdobrar-se fecundamente em polêmicas, artigos, novas perspectivas, cotejos, reformulações. O público das Bienais caracterizava-se, assim, por uma euforia, um anseio de participação que o levava a superar os maiores entraves. Quando o júri não foi suspeito? $\mathrm{Ou}$ o prédio aceito como adequado? Ou os executivos e funcionários da casa amados como paradigmas de cultura? Ou as obras dispensadas de lenta e apaixonada triagem, realizada individualmente, sem recusas precipitadas ou delegações de poder? Em contrapartida, nesta última o visitante chegava sem nenhuma flama, olhava distraído, projetava seu desinteresse e saía com a indesmanchável condenação: não há nada para ver, são tendências muito superadas, já vi tudo isso mil vezes, os artistas não mais se renovam, ou qualquer outra platitude do gênero.

Como não poderia deixar de ser, até os mais importantes sucessos da equipe organizadora acabaram devorados pelo torpor coletivo:

$\square$ o reinício das exibições paralelas de cinema, coordenadas por Paulo Emílio, com filmes da Vera Cruz

a peça Victor ou as crianças no poder, dirigida por Celso Nunes

\section{o melhor nível cultural dos moni- tores}

$\square$ o projeto de instalar um grupo de pesquisadores, em funcionamento contínuo, a fim de reunir o material didático necessário às próximas Bienais

a promessa de uma futura escolinha de arte para crianças

Os membros da diretoria da Fundação Bienal, apesar da carência de tempo (que, aliás, deveriam conhecer mais precisamente do que ninguém) toparam o desafio e correram contra o destino: enfileiraram no pavilhão um razoável conjunto de trabalhos visuais, onde nem tudo era material de segunda mão ou tuta-e-meia. É verdade que um acervo prejudicado por lacunas e desordens formado em vôo cego e no escuro, para resumir a questão. Contudo, ainda assim mais excitante, mais provocador do que merecia talvez o conformismo, a mesmice, a apatia reinantes.

Poderia haver uma adversidade mais imbatível do que esta população de fim de festa?

Deve-se confessar, para sermos justos, que este público atual não foi um privilégio da Bienal de São Paulo. Longe disso! Ouve-se a mesma queixa de todos os lados. Cineastas, jornalistas, poetas, músicos, alunos e professores, amadores ou profissionais, quase toda a inteligência nacional vem registrando essa melancólica falta de ressonância. As coisas se passam como se os parceiros do diálogo não mais integrassem as propostas, por falta de perspectiva, desânimo generalizado ou, para falar com Antônio Cândido, "migração interior" (4).

A obra de arte participa das correntes subterrâneas coletivas, segundo a formulação de Adorno. E os clientes das instituições culturais também não pode riam fugir a esta regra de ouro, gostaríamos de acrescentar. As reações diante da XIII Bienal acabam por desenhar uma figura altamente reveladora: o rosto dessa entidade às vezes um pouco abstrata e difusa, o grande público consumidor de cultura do Brasil, o homem instruído de um tempo cruel: reversão das expectativas, crise do petróleo, insatisfação universitária, inflação, censura. Afinal, na hora que passa, quem não tem medo de se deixar envolver pelas obras de arte?

(4) Em recentes declarações à revista Banas, ano 22, n. 1109,15 a 28 de set. de 1975 , p. 42 a 46. 


\section{Latinoamericanidad}

Vejamos então um caso saliente, bem exemplificativo do que se tentou colocar. Segundo Landmann, no discurso inaugural, esta Bienal marcaria uma espécie de abertura para a América Latina. Acenava-se, inclusive, com as vantagens da criação de uma entidade paralela ao embrionário mercado comum latino-americano, que se dedicasse ao Intercâmbio artístico "sem fronteiras físicas nem divergências ideológicas". A XIII pretendia dar um sinal de partida, ao convidar hors concours alguns artistas já consagrados desta região terceiro mundista: Cuevas (México), Brizzi (Argentina), Negret (Colômbia), Mário Toral (Chile), Hernandez Cruz (Porto Rico) e Szyzlo (Peru).

$\mathrm{O}$ apelo não obteve, entretanto, a esperada audiência. Em primeiro lugar, porque logo se suspeitou que fosse apenas uma tábua de salvação, arranjo de última hora, efeito publicitário para disfarçar o vácuo imperante. Depois, porque as referidas salas especiais também não conseguiram despertar maiores entusiasmos. $\mathrm{E}$ nem poderia mesmo ser diferente. Cuevas - sem dúvida, o único de primeira grandeza - já era bastante conhecido, por meio de revistas especializadas. Os outros, de sua parte, nada ofereciam de sumamente original, avaliados no âmbito do panorama internarional ou mesmo em função de nosso dia a dia provinciano.

De resto, os que concorriam à premiação, enviados pelos países de origem, também não fugiam ao rotineiro e só reforçavam a mornidão geral. Limitemo-nos àqueles que receberam distinções:

Joyce, da Guatemala, Prêmio Matarazzo Sobrinho, por suas esculturas de aço inoxidável, simplórias variações a partir da figura do círculo, mero trabalho de principiante que se acha ainda em fase de assimilação de tendências cosmopolitas.

Maria Simon, da Argentina, um dos prêmios internacionais mais questionáveis, pelas suas esculturas de metal e sucata, irritantemente envelhecidas e superadas tanto na concepção quanto na execução

Carlos Rojas, da Colômbia, também prêmio internacional, que repete as soluções de Kenneth Noland, sem o menor traço de originalidade

$\square$ Edith Gimenez, do Paraguai, prêmio internacional por suas gravuras em papel arroz, que mal lograriam destacar-se numa retrospectiva da gravura paulistana (para não irmos mais longe)

Mas havia exceções que escapavam ao desastre geral e faziam jus a melhor destino. Bastaria mesmo a presença delas para realimentar a discussão - a cada dia mais oportuna e inadiável - sobre as reais possibilidades latino-americanas no domínio da vida cultural. Ao analisá-las já se pode tomar consciência da enorme perda que sofremos devido ao sistemático cultivo de um dos vícios continentais por excelência: a incomunicabilidade entre os nossos vários países, a falta de uma dinânima e constante troca de experiências. Referimo-nos

ao argentino Roux, ganhador com total justiça de um dos prêmios internacionais, por suas reproduções (a aquarela) de fragmentos de obras-primas da pintura mundial, deslocados e reestruturados em novos conjuntos, de modo a originar assim as mais inusitadas significações. No caso da Gioconda, por exemplo, sua técniva leva à explicitação de conteúdos sexuais que estariam latentes no quadro inspirador: uma espécie de re-visão freudiana assessorada pelas tesouras de Matisse.

e a Manuel Felguérez, que recebeu a Grande Distinção Honorífica, sem premiação em dinheiro. O mexicano 
opera na fronteira entre o artesanato mais comum e o uso da tecnologia dos computadores para fins estéticos. Num primeiro momento, os esquemas visuais são analisados por meio desses aparelhos eletrônicos; constrói-se assim uma estrntura formal, que servirá de modelo para a fatura de séries completas de obras de tipo convencional — serigrafias, relevos, pinturas e esculturas — nos quais são manipulados recursos técnico-expressivos próprios a cada uma destas disciplinas. Mas, em última instância, se tomarmos os produtos como objetos acabados (como seres desligados do processo de produção) não haverá qualquer traço que sirva para distingui-los dos usuais relevos, gravuras, pinturas e esculturas do abstracionismo geométrico. Desta maneira, os vínculos dos trabalhos de Felguérez com a estética do computador, ora em período de definição, tornam-se puramente mecânicos e exteriores. À computer art não estariam prometidos caminhos mais essenciais? Sem dúvida interessa à América Latina modernizar-se através do emprego da tecnologia avançada. Desde que nos desembaracemos, porém, de uma vez por todas, das formações de compromisso. Ascenderemos a tal nível? $\mathrm{Ou}$ talvez nos sejam mais acessíveis os requintes na exploração dos meios simples, artesanais, de pura sensibilidade pessoal, como parecem indicar as aquarelas de Roux?

São questões à espera de uma recogitação. Talvez valesse a pena organizar (e financiar) uma "cerimônia custosa e arcaica" (5), desde que se conseguisse ao menos repor em circulação, com toda ênfase, problemas desta ordem. Contudo, a ausência de um caldo de cultura bloqueou os estímulos. $\mathrm{O}$ indiferentismo acabou por dissolver no mesmo "estado de geléia" tanto o suntuoso projeto

(5) A expressão é de Mário Pedrosa, em Mundo, Homem, Arte em Crise. São Paulo, Perspectiva, 1975, p. 300. oficial quanto a meditação acerca das experiências mais curiosas. Infelizmente a XIII Bienal de São Paulo não significou a hora e a vez da latino-americanidade.

\section{Ver a vídeo}

Os norte-americanos fizeram construir, logo à entrada, um verdadeiro museu dentro do museu, para abrigar a Video Arts USA, retrospectiva organizada pelo Centro de Artes Contemporâneas de Cincinatti. Compreendia 750 metros quadrados, quatro salas fechadas, mais de cem poltronas, saída de emergência, boa acústica, temperatura regular, dezenas de aparelhos de televisão. Os japoneses, logo em frente, iam de carona em todo esse esforço promocional e mostravam três pesquisas na mesma direção: "o vldeo colocado a serviço da arte", para dar livre curso ao slogan tantas vezes repetido por Jack Boulton. Assim sendo, havia um considerável leque de opções estéticas, dentre as quais selecionaremos algumas:

$\square$ um misto de peça escultórica e estruturação de ambiente artificial, o Jardim de $T V$, executado em 1974 por Nam June Paik, considerado "a figura ancestral" deste gênero de arte, por ele pioneiramente desenvolvido nos Estados Unidos desde o início da década de 60. Trata-se de um híbrido conjunto de vinte monitores (15 a cores), todos ligados sem interrupção, dispostos num lago ou poço quadrado, entre flores e plantas naturais, com as telas voltadas para cima, podendo ser contempladas pelos interessados que se aglomeravam em plataforma circundante. $O$ tape exibido era um dinâmico, ágil mosaico que nos bombardeava alternadamente com Bill Haley e Ginsberg, cenas do Living e Cage, indígenas, músicos coreanos, Nixon - uma ilustração do que po- 
derá vir a ser a única forma de experiência cultural na época da aldeia global. Mas ilustração de evidentes intenções paródicas e não para ser consumida a sério (um trailler do Fantástico), como ocorreu em quase todas as oportunidades e nas mais diversas faixas de público.

$\square$ uma peça de participação, Sev, de Peter Campus, na qual uma câmara apanha o visitante por trás e projeta-lhe a imagem numa parede branca, de tal sorte que o sujeito tem a impressão de ver-se em três dimensões e através da parede, efeitos conseguidos por meio de luzes infravermelhas. Vizinha desta é a experimentação de Katsuhiro Yamaguchi, prêmio Indústria Villares, onde as imagens dos espectadores-participantes são projetadas numa grande reprodução do quadro As Meninas, de Velazquez, . sua efígie passando a mover-se entre os seres ali representados.

As maiores surpresas, no entanto, aguardavam-nos nas áreas equipadas com monitores de vídeo. Uma boa trintena de obras era aí exibida permanentemente: tapes de Warhol, Kaprow, Serra, Baldessari, para só nomearmos estas figuras exponenciais. Afloravam as mais diversas orientações de pesquisa: investigações sobre a própria natureza da percepção visual; documentos e análises críticas da vida social, inclusive sátiras à televisão comercial; jogos formalistas e estetizantes, como as sequiências de lentas metamorfoses de objetos e processos naturais; buscas de efeitos de profundidade e de aproximação, deformações e alterações espácio-temporais; entrelaçamentos requintadíssimos entre sons e imagens; enfim, um sem-número de resultados obtidos graças à moderna parafernália da TV portátil, leve e econômica, com seus cassetes, sintetizadores, processos de computadorização.

Mas seria injusto limitar a vídeo-arte apenas a uma conseqüência das inven- ções ocorridas neste domínio tecnológico. Há uma outra face do mesmo prisma, que é a assimilação dos aportes mais especificamente culturais e ideológicos. A vídeo nasceu e cristalizou-se - não por coincidência, está claro - em países já altamente industrializados, porém no interior de uma rede de influxos do movimento underground, do free-cinema, da arte na universidade, do fastígio do super-oito, dos happenings e autoteatralizações, do interesse pela cibernética e pela teoria da informação, dos protestos, contestações e resistências civis. Não alonguemos demais a lista, pois não é o que visamos neste momento. Queremos só lembrar, de passagem, que uma das responsabilidades da vídeo-arte, nesse contexto de invenção e polêmica, seria também de natureza muito decisiva: dar, à sua maneira e com os seus recursos, o maior auxílio possível na tarefa coletiva de desconstrução dos hábitos criados pelo sistema da indústria cultural. Não devemos encará-la, portanto, como mais uma engenhoca destinada a fabricar sonhos alienantes ou mitos que divertem e gratificam. Ao contrário, nas palavras de Boulton: "A vídeo-arte é tediosa. Que não se espere algo excitante, condicionados como estamos a informações comerciais, onde não existe o questionamento e a reformulação do tempo, nem a contemplação" (6).

No entanto, apesar de todos esses requestionamentos, que necessariamente deveriam ser levantados e desenvolvidos, o clima de inércia resistiu aos impactos e sugestões. O público entrava, dava um vistaço geral de cinco ou dez minutos e depois batia em retirada: não era a telenovela costumeira, aquele cidadão falando obsessivamente "eu estou fazendo arte"; e também não era O Repórter aquele sujeito que filmara

(6) Declarações a O Estado de São Paulo, 19 de outubro de 1975 , p. 25. 
uma cidadezinha da América do Norte, na comemoração do Dia da Independência, registrando fatos e episódios aparentemente secundários e inexpressivos.

$\square$ um funcionário da casa, entre irônico e decepcionado, narrava para quem desejasse ouvir uma fábula muito instrutiva: poder-se-ia contar nos dedos de uma só mão o número de profissionais (artistas, críticos e professores de arte) que se dispuseram a enfrentar a maratona. $O$ que não impedia, bem entendido, que todos saíssem com julgamentos formados e definitivos. Pior ainda: quase sempre negativos - eram estandes para vender aparelhos, filminhos que saturavam devido à lentidão, truques ingênuos, perigosa escravização do homem à máquina, e assim por diante, ad nauseam.

Positivamente, os membros do júri não estavam desacompanhados: havia na Bienal XIII uma legião de pessoas com medo de gastar dez, quinze, vinte horas a fim de ver/selecionar/compa$\mathrm{rar} /$ rever infatigavelmente as propostas da vídeo. Afinal, mudou só a Bienal de São Paulo ou teria mudado principalmente o ânimo de seus freqüentadores?

\section{A outra volta do parafuso}

Um eixo imaginário desta Bienal comportaria dois pontos extremos: de um lado, as experimentações com técnicas e processos recém-surgidos (Felguérez, a vídeo); de outro, o emprego dos recursos plásticos mais tradicionais, simples e familiares, como se estivesse ainda muito distante um real esgotamento das suas potencialidades. Não se confunda, porém, esta aceitação tranqüila - para efeito de uma reesploração de seus limites - com mera sobrevivência acadêmica. Seus praticantes levam sempre em consideração, como aliás não poderia deixar de ocorrer, a crise dos gêneros e formas lingüísticas, que é uma das características do nosso universo cultural. Por isso, incorporam também muitos esquemas e soluções de vanguarda, enriquecendo e tornando mais e mais complexos seus trabalhos.

Mencionemos em especial:

Rick Poot, escultor belga, voltado para a apreensão dos gestos e ritmos humanos, bem próximo das tradições expressionistas, articulando peças de bronze através do procedimento da cera perdida, método já antiquíssimo e no entanto se revelando sempre muito capaz de ajustar-se às sucessivas modernizações da temática

Tadeus Brzozowsky, pintor polonês que se utiliza ainda uma vez dos efeitos visuais latentes nas assim chamadas "qualidades plásticas" - empastamentos, jogos de luz, modulações de tons, fusões de cores.

Kim Whanki, pintor abstrato da Coréia do Sul, uma das mais gratas surpresas desta mostra, com suas imensas telas de pintura-pintura, justapondo e sobrepondo zonas de cor, de modo poético e intimista

Contudo, na sala de desenhos ingleses, organizada pelo British Council, é que se poderia confirmar na íntegra esse amoroso reencontro com meios de produção já seculares - lápis, crayon, bico de pena, giz, guache, aquarela, óleo. A coletiva englobava, de uma só vez, Hockney, Peter Blake, Bridget Riley, Colin Self, Richard Smith e mais uma dezena de outros nomes de igual importância. A problemática assim definida oscilava da visão lírica e contemplativa (nos retratos de Hockney, por exemplo) à crítica virulenta de Michel Sandle (Drawings towards monument for America: flayed Mickey Mouse and machine gun in bronze), da tematização dos efeitos ópticos nos esboços de Riley à integração dos fios de arame em superfícies homogeneamente coloridas nos multimedia de Richard Smith. 
No Catálogo, igualmente de exemplar qualidade, Norbert Lynton observou com lucidez:

"O desenho não só sobreviveu, como parece ter assumido um valor novo e, mais ainda, uma nova escala de funções. Mais uma vez, um repto, dos que têm ocorrido no desenrolar da história da arte moderno, o que fez foi valorizar o objeto contestado, deslocando-o de um plano convencional e dando-lhe novo sentido".

Ora, o repto inverso também deveria mostrar-se altamente produtivo. Em confronto direto com o grafismo britânico talvez a vídeo pudesse ser levada a ostentar melhor suas reais virtualidades, esperanças e significações profundas. Mas faltou gás, energia, fôlego para que se esboçasse uma confrontação de tal ordem, que exigiria vis polemica em lugar do que Frederico Morais denominou recentemente "fossa cultural" (7). Houve, isto sim, apenas uma exaltação unilateral e apologética dos desenhistas ingleses: desde o visitante mais ingênuo até os membros do júri (que fizeram seu elogio constar em ata), nenhuma voz discordante. Não era bem isso que se esperava, todavia, como reação a uma Bienal de São Paulo. Inclusive, pouco ou nada acrescenta à glória daqueles jovens mestres. Infelizmente vale para as restaurações dos "valores plásticos". Nostalgia perfeitamente encaixada no quadro gral de melancolia e desencanto. Embora muito inadequada aos artistas em exame, na certa desassossegados no reacionário papel que lhes foi atribuído: o de fantasmas que se limitavam a testemunhar a favor do passado.

(7) Frederico Morais - Artes Plásticas: a crise da hora atual. Rio, Paz e Terra, 1975, p. 102. "Um sentimento negativista de que não há muito mais o que fazer", esclarece logo em seguida o autor, à mesma página.

\section{Cena Brasílica}

O conjunto reunido para mostrar a atual situação artística brasileira não conseguiria resistir à menor análise crítica. E mais uma vez se deve reconhecer que a equipe da Fundação Bienal não é a única responsável pelo naufrágio. Já é do domínio público o impasse que se instalou há vários anos: o boicote eficiente e sistemático à Bienal de São Paulo, por parte dos trabalhadores de arte no Brasil. De um lado, por razões político-ideológicas: não colaborar em nenhuma manifestação oficial. De outro, por motivos estritamente profissionais: as galerias comerciais e grandes retrospectivas têm-se revelado mais produtivas como veículos de popularização.

Assim, neste caso particular, o estado de ânimo do público era o mais ajustado e condizente possível: dar uma passada geral, limitar-se à espiadela sem compromisso e não refletir sobre o material exposto. No melhor dos casos, sair correndo em busca da arte nacional mais significativa: mestre Volpi no Museu de Arte Moderna, prédio vizinho; Panorama da Escultura e Objeto, no mesmo local; ou as galerias da cidade, oferecendo Júlio Plaza, Nelson Leirner, Maria Leontina, Mario Gruber.

Por reconhecermos a necessidade de se tentar constituir uma memória nacional, em todas as oportunidades, e mesmo que seja preciso forçar um pouco a mão, vamos registrar duas ou três observações de caráter geral:

já citamos a Sala Brasília, organizada nas últimas semanas, às pressas. $O$ resultado não poderia mesmo ser diferente: um grotesco bricabraque. Antigos premiados, que continuam em plena forma, aí conviviam com veteranos esgotados na sua capacidade criadora; figuras históricas de primeira plana como Anita, Brecheret, Flexor, Bona- 
dei, Rebolo - surgiam de repente ao lado de sujeitos que expõem sempre o mesmo trabalho inexpressivo e mal acabado; jovens que têm ainda uma brilhante carreira pela frente eram prejudicados por sombras de jovens que nasceram velhos. Tudo absolutamente lastimável como informação, péssimo como retrospectiva, nulo do ponto de vista museológico. E pensar que nesse cafarnaum se encontravam Fayga, Odriozola, Juarez Magno, Tomie, Isabel Pons. Mas a que preço!

No mezanino, logo depois das salas especiais para a América Latina, achavam-se os trabalhos dos que concorriam a prêmios. Aqui, a sensação de uma heteróclita miscelânea era mais justificada ainda. Misturavam-se ao acaso pelo menos duas camadas distintas: um bom número de peças selecionadas por ocasião da Bienal Nacional de 1974 e outro tanto de obras escolhidas por comissão recente, uma vez que se temia pela sorte do raquítico e insignificante acervo preliminarmente constituído. Acontece, porém, que os critérios diferiam. Da primeira camada emergiam, com força especial, obras que se aproximavam das raízes populares e folclóricas, quando não saíam diretamente delas. A segunda opção, no estanto, privilegiava claramente as proposições urbanas, cultas, de livre trânsito no cenário internacional. Mas, principalmente, faltava nesse acampamento do exército de Brancaleone, uma orientação aos visitantes, divisões nítidas, painéis didáticos, enfim uma separação dos vários níveis, intuitos e momentos do processo.

$\square$ Daqueles exercícios mais vinculados às tendências cosmopolitas nada de relevante se teria a dizer. Quase sempre eram apenas subprodutos que se diluíam no lugar-comum e raramente ultrapassavam a média encontrável em qualquer salão de principiantes. Algumas se des- tacavam até mesmo pelo excesso de pretensão imotivada. Sempre, do Grupo Convívio, por exemplo: um agrupamento de oito gigantescas cabeças, formando um corredor que desembocava em recinto semelhante a um templo arcaico. Outras, inversamente, talvez pecassem por humildade extrema, como as gravuras de Evandro Carlos Jardim, executadas em branco-e-preto, por meio de traços muito finos e delicados, que vão sugerindo figuras, objetos, pássaros. Sem dúvida, resultavam de pesquisa já amadurecida, com brilhantes achados técnico-formais, merecendo amplamente o Prêmio da Prefeitura de São Paulo. Mas careciam um pouco de maior ousadia, da indispensável dose de temeridade no ato de criar, que marca a fronteira entre o simples artesão e o inventor fora de série.

$\square$ o júri destacou igualmente a pintura de Siron Franco, atribuindo-lhe um dos prêmios internacionais. "Sem timidez de ser o que é: pintura", comenta Roberto Pontual no catálogo individual do jovem pintor goiano. Acresça-se o fato de que Siron também não se poupa de tentar ser o que ainda não é - um pintor maior. Mas isso, bem entendido, talvez só por curto espaço de tempo, uma vez que possui de fato a elementar coragem de assumir todos os riscos da empresa. Começou por dominar as lições da técnica mais tradicional e pela definição de uma temática ao mesmo tempo pessoal e capaz de ressonâncias coletivas. Ou seja, faz exatamente o que poucos se animam a empreender: instrumentaliza-se e toma posição diante dos dramas universais. Nesse sentido, como reconhecimento da promessa que incarna, parece-nos bastante louvável a premiação deste rebento - algo tardio, é verdade - do surrealismo e da arte fantástica, com seus personagens a meio caminho entre o bestial e o humano, o onírico e o mais corriqueiro dia a dia. Há contudo um temor que desejamos 
confessar - o "festejamento prematuro" de um talentoso principiante, nem sempre com o "estofo necessário para resistir ao tempo e às solicitações que seu nome levanta", como escreveu certa vez Aracy Amaral . De que forma reagirá Siron Franco?

Como lembramos anteriormente, a seleção de 74 representara em larga medida uma oportunidade para os que buscam inspirar-se nas tradições populares. Nenhuma hesitação de nossa parte quanto ao valor do critério em si sempre peferiríamos ver no pavilhão nacional um desconhecido e original artista primitivo em lugar da inflação de repetitivos e descaracterizados objetos cinéticos, primários ambientes de ficção científica ou insossos apelos a favor das áreas verdes. E na prática, observando as obras expostas, convenceram-nos plenamente as esculturas de Mestre Dézinho, anjos e crucifixo em blocos de madeira polida e envernizada, surpreendentemente elegantes e graciosas. Fascinaram-nos também as peças em madeira de Valentim Rosa (chamado "o repentista do cinzel"), calungas toscos e inquietantes, devido às sugestões de mistério que despertam, parecendo brotar dos galhos e raízes como figurações do inconsciente coletivo. Em contrapartida, já bem afastadas das mais autênticas fontes populares se encontram as estilizações do candomblé e outros ritos afro-americanos por Jonas dos Santos, ou a procissão de ex-votos nordestinos que Ederson Medeiros reconstruiu. Sendo tão reduzida a mostragem exibida, a Bienal de São Paulo fica assim nos devendo, desde agora, um levantamento mais exaustivo e rigoroso, a fim de localizar e depois divulgar o imaginário brasileiro ainda inédito, e que talvez possa realmente surgir como alternativa, quando em confronto direto com as fórmulas culturais importadas e passivamente aplicadas. Ou será que todas essas promessas não vão além de uma mitologia para ninar o homo urbanus da época das multinacionais?

Havia um embrião de resposta na ambientação armada pelo grupo Etsedron - Nordeste, de trás para diante. Edson Luz e seus companheiros levantaram no recinto da Bienal, em pleno Parque Ibirapuera, no coração de uma das cidades mais industrializadas do continente, a imagem dolorosa e pungente do mundo rural nordestino, com seus quadros de miséria e dor - o parto, a morte, as superstições, a fome, a seca. Materiais usados: cipó, caveiras de bichos, madeira, varas, pano, estopa, terra vermelha no chão, músicas e sons, dança e rituais daquela região. $\mathrm{O}$ coletivo trabalho interdisciplinar, por seu grande impacto e poder de comoção, era uma pesquisa em condições de realmente compensar o exagero de formas, soluções e esquemas de segunda mão, que tanto prejudicavam a seção brasileira. À saída inscreveram: "E se chegar em casa / Ainda tiver um pouco / De barro nos pés / Lembre-se do Nordeste". Mas quem poderia esquecer-se, depois de uma síntese tão expressiva? Ainda mais pegajoso que o barro, com certeza, é o símbolo que elaboraram de modo tão perfeito e convincente, sem qualquer folclorismo de superfície. Símbolo que adere à consciência e ajuda a pôr em xeque todos os conformismos, indiferenças, tédios, fossas, autocensuras, entorpecimentos, mornidões, migrações interiores.

\section{Legado maior}

As bienais deveriam ser, por princí pio, uma ilustração do que se está fazendo de mais experimental no momento. Além disso, poderiam assumir também o papel de "retrospectivas de vanguarda" para usar os termos de Décio Pignatari. Aceitas estas premissas, 
não se tem como negar: as salas Xingu Dia Noite Terra ocupavam uma posição algo irregular no conjunto da Bienal XIII. Mas ainda bem que ali estavam, exercendo forte atração sobre o público (só os quadros de Toral suscitaram igual admiração) e merecendo elogios unânimes dos especialistas. Repetia-se assim o que já ocorrera na VII Bienal, quando a arte pré-colombiana chamou para si os grandes méritos da exposição. Tudo isso, por sinal, se nos afigura bastante incomodativo: a hora que passa não é das mais felizes, a ponto de preferirmos, quando dos eventuais cotejos, as obras mais longínquas no tempo ou no espaço geográfico. A coruja de Minerva levanta seu vôo porque estamos numa pior?

$\square$ o arquiteto Fernando Lion foi o encarregado da montagem final, que contou ainda com o auxílio do cacique altoxinguano Aritana. $\mathrm{Na}$ primeira sala dispuseram alguns objetos de uso cotidiano, pertencentes à coleção dos irmãos Villas-Boas - vasos, peneiras, arcos e flexas, banquinhos, instrumentos musicais - notáveis pela funcionalidade e elegância das formas, baseadas nas figuras geométricas elementares e nas cores puras, capazes de suportar assim qualquer comparação com o mais sofisticado design.

na segunda sala obtiveram uma sugestão de ambiente cotidiano nas aldeias do Xingu: maravilhosos painéis fotográficos, em material translúcido, de Maureen Bisilliat (outra idealizadora da exposição), apresentando o elemento nativo em tamanho natural, desenvolvendo seus afazeres mais comuns pesca, dança, caça; filme de Marcelo Tassara, documentando inclusive a luta do Kuarup, em homenagem aos mortos; trilha sonora com ruídos da floresta virgem, as vozes dos indígenas conversando ou cantando; e todas essas preciosidades organizadas no recesso de uma oca, contando até mesmo com a luz crepuscular, semelhante àquela que lhe seria natural.

Emanava desse conjunto uma atmosfera quase religiosa, a reação inevitável sendo uma mescla de espanto, comoção e extrema veneração. Não haveria retórica que pudesse verbalizar um tão grande encantamento com o peso de cada gesto, com os laços que unem cada ritmo a um passado infinito, com a significação coletiva que se atribui ao fabricar, ao comunicar-se, ao estabelecer nexos vitais com o mundo circundante. No modelar catálogo (editado pela Secretaria da Cultura do Estado de São Paulo, que foi a patrocinadora desta mostra), escreveram os Villas-Boas: "De tudo isso fica a impressão, quase a certeza de que o índio, o meio que o cerca, sua cultura material e espiritual fazem parte de um todo indivisível, ajustado ao tempo, num equilíbrio que nós, civilizados, perdemos há muito, no passado distante, e talvez para sempre".

Depois do aprendizado de uma tal harmonia, que perdão haverá para os afobados homens de empresa, já começando a pensar na promoção social que lhes trará a XIV Bienal? Ou para aqueles produtores que sempre costumam deixar para a última hora a execução final de seus trabalhos? Ou para os que se confinam aos estéreis jogos formais e estetizantes? Ou para os comerciantes que se apressam em remarcar os preços, em função dos prestígios ou desprestígios alcançados por suas mercadorias? Ou, last but not least, para os escritores de arte que se recusam a uma reflexão mais demorada sobre os fundamentalíssimos problemas levantados por esta Bienal, pois já se sentem chamados por novos salões, vernissages, retrospectivas? Afinal, a quem tudo isso beneficia?

Lição de índio: coisa bonita tem que ser feita devagar. 